\title{
Partial Deficiency of Zfp217 Resists High-Fat Diet-Induced Obesity by Increasing Energy Metabolism in Mice
}

\author{
Qianhui Zeng (D, Nannan Wang, Yaru Zhang, Yuxuan Yang, Shuangshuang Li, Rong Zheng, Jin Chai, Tong Qiao \\ and Siwen Jiang *
}

Citation: Zeng, Q.; Wang, N.; Zhang, Y.; Yang, Y.; Li, S.; Zheng, R.; Chai, J.; Qiao, T.; Jiang, S. Partial Deficiency of Zfp217 Resists High-Fat Diet-Induced Obesity by Increasing Energy Metabolism in Mice. Int. J. Mol. Sci. 2021, 22, 5390. https:// doi.org/10.3390/ijms22105390

Academic Editor: Grażyna Nowicka

Received: 22 April 2021

Accepted: 11 May 2021

Published: 20 May 2021

Publisher's Note: MDPI stays neutral with regard to jurisdictional claims in published maps and institutional affiliations.

Copyright: (c) 2021 by the authors. Licensee MDPI, Basel, Switzerland. This article is an open access article distributed under the terms and conditions of the Creative Commons Attribution (CC BY) license (https:/ / creativecommons.org/licenses/by/ $4.0 /)$.
Key Laboratory of Animal Genetics, Breeding and Reproduction Ministry of Education, College of Animal Science and Technology, Huazhong Agricultural University, Wuhan 430070, China; zengqianhui2021@163.com (Q.Z.); genewangnannan@gmail.com (N.W.); z15563102012@163.com (Y.Z.); yangyuxuan261@163.com (Y.Y.); lishuangshuang188@163.com (S.L.); zhengrong@mail.hzau.edu.cn (R.Z.); chaijin@mail.hzau.edu.cn (J.C.); qiaotong2021@163.com (T.Q.)

* Correspondence: jiangsiwen@mail.hzau.edu.cn; Tel.: +86-27-8728-0302

\begin{abstract}
Obesity-induced adipose tissue dysfunction and disorders of glycolipid metabolism have become a worldwide research priority. Zfp217 plays a crucial role in adipogenesis of 3T3-L1 preadipocytes, but about its functions in animal models are not yet clear. To explore the role of Zfp217 in high-fat diet (HFD)-induced obese mice, global Zfp217 heterozygous knockout (Zfp217 ${ }^{+-}$)

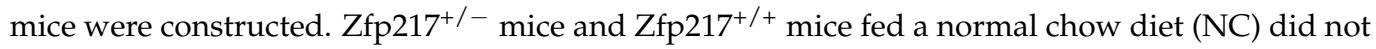
differ significantly in weight gain, percent body fat mass, glucose tolerance, or insulin sensitivity. When challenged with HFD, Zfp $217^{+/-}$mice had less weight gain than $\mathrm{Zfp} 217^{+/+}$mice. Histological observations revealed that $\mathrm{Zfp} 217^{+/-}$mice fed a high-fat diet had much smaller white adipocytes in inguinal white adipose tissue (iWAT). Zfp217 ${ }^{+/}$mice had improved metabolic profiles, including improved glucose tolerance, enhanced insulin sensitivity, and increased energy expenditure compared to the Zfp $217^{+/+}$mice under HFD. We found that adipogenesis-related genes were increased and metabolic thermogenesis-related genes were decreased in the iWAT of HFD-fed Zfp217 ${ }^{+/}$mice compared to $\mathrm{Zfp} 217^{+/-}$mice. In addition, adipogenesis was markedly reduced in mouse embryonic fibroblasts (MEFs) from Zfp217-deleted mice. Together, these data indicate that Zfp217 is a regulator of energy metabolism and it is likely to provide novel insight into treatment for obesity.
\end{abstract}

Keywords: Zfp217; obesity; adipogenesis; glucose tolerance; insulin sensitivity; energy expenditure

\section{Introduction}

Obesity is a key risk factor for many chronic diseases, including type 2 diabetes, cardiovascular disease, and cancer [1-4]. When energy intake exceeds energy expenditure, the body stores energy mainly as triglycerides, which leads to excessive growth of adipose tissue [5]. Principal characteristics of obesity are adipocyte hypertrophy and hyperplasia [6]. With the worldwide obesity epidemic, it remains important to study adipocyte growth and development, adipose tissue regulation of energy homeostasis, and glucose homeostasis.

Adipose tissue is an important metabolic organ, whose main function is an energy storage site under conditions of energy excess [7] and can also secrete several endocrine hormones such as adiponectin [7,8]. Adipose tissue mediates the regulation of glucose lipid homeostasis and is essential for systemic insulin sensitivity and energy balance $[9,10]$. Adipose tissue consists mainly of adipocytes, which undergo a multi-step directed process to generate pre-adipocytes when they encounter stimuli, which are subsequently activated by many regulatory factors (signaling pathways and transcription factors) under lipogenesis-inducing conditions to differentiate into adipocytes [11-13]. Several reviews have systematically summarized the molecular regulatory mechanisms of adipogenesis and constructed a transcriptional cascade regulatory network [14-16]. There 
are two major adipogenic factors at the core of this network, PPAR $\gamma$ and $\mathrm{C} / \mathrm{EBP} \alpha$, which play a key role in systemic lipid and glucose metabolism [17-19].

Numerous studies have shown that zinc finger protein (ZFP) has an essential role in fat biology [20]. For example, KLF5 knockout mice are protected against high-fat diet-induced obesity, with impaired adipogenesis in mouse embryonic fibroblasts (MEFs) of KLF5 ${ }^{+/-}$ mice [21,22]. Zfp407 regulates glucose homeostasis and insulin sensitivity by regulating GLUT4 transcript levels and PPAR $\gamma$ activity in response to insulin stimulation [23]. Zinc Finger Protein 217 (Zfp217) belongs to the Krüppel-type transcription factors [24]. Recent studies have revealed that $Z f p 217$ is also involved in adipogenesis, through interaction with histone methylation enzyme EZH2 to promote adipogenesis by influencing cell cycle [25]; through the interaction of Zfp217 and m6A methyltransferase METTL3 or demethylase FTO, the m6A modification level of related downstream target genes is influenced and mediates post-transcriptional modifications of $\mathrm{m6A}$ in a YTHDF2-dependent manner, thereby affecting adipocyte differentiation, suggesting that Zfp217 could play an important role in adipogenesis at the level of transcription and post-transcriptional modifications [26,27]. However, the function of Zfp217 in in vivo animal models is largely unknown.

In the present study, using a novel heterozygous mouse model, we observed that partial deficiency of Zfp217 mice fed high-fat diets presented less body weight accompanied by improved glucose tolerance, increased insulin sensitivity, and energy expenditure. Accordingly, these data show that Zfp217 functions as a regulator of systemic energy metabolism in a live animal model.

\section{Results}

\subsection{Generation of Zfp217 Heterozygote Mice}

To elucidate the physiological role of Zfp217 in vivo, whole-body Zfp217-knockout mice were generated using the CRISPR/Cas9 system (Figure 1A). We also performed a test for the probability of sgRNA off-target before the start of the experiment. Results from agarose gel electrophoresis showed no genome editing in any of the five most probable off-target sites (Figure S4). To generate homozygous Zfp217 knockout mice, we intercrossed heterozygous Zfp217 $7^{+/-}$mice in the earlier experiments. Unfortunately, we found Zfp217 homozygous null mice are embryonically lethal and no live mice were detected. According to the previous literature, we learned that knockout Zfp217 has effects on exiting from pluripotency in embryonic stem cell (ESC) differentiation, possibly because Zfp217 expression is rapidly decreased and METTL3 is released to maintain of $\mathrm{m}^{6} \mathrm{~A}$ methylation of pluripotent transcripts, which causes embryonic stem cell differentiation [28], or NuRD mediates H3K27 acetylation and PCR2 mediates H3K27 trimethylation to silence the ESC differentiation-related gene [29]. The causes of lethality in Zfp217 homozygous null embryos, however, remain unclear. To circumvent this problem, we used Zfp217 ${ }^{+/-}$ mice in the present study. Inter-crossing of heterozygote mice with WT (wild type) mice yielded Zfp217 knockout $\left(\mathrm{Zfp} 217^{+/-}\right)$and WT $\left(\mathrm{Zfp} 217^{+/+}\right)$littermates. Genotypes of mice were identified through PCR (Figure 1B). The distribution of genotypes was in accordance with the Mendelian ratio, and the appearance of the newborns was normal. Subsequently, quantitative real-time PCR analysis on inguinal white adipose tissue (iWAT), epididymal white adipose tissue (eWAT), brown adipose tissue (BAT), and liver showed that Zfp217 mRNA levels were approximately $50 \%$ lower in the Zfp217 / - mice compared to Zfp217 $7^{+/+}$ littermates (Figure 1C). These results showed that the model of Zfp217 systemic knockout mice was generated successfully. 
A
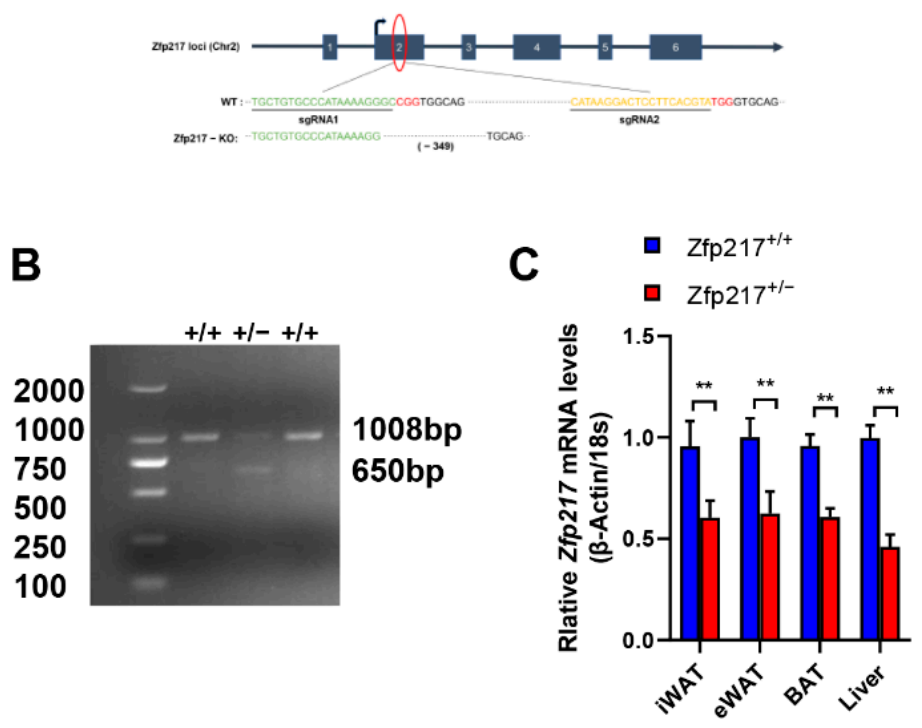

Figure 1. Generation of whole-body Zfp217 knockout mice. (A) Schematic of a gene-targeting strategy to create Zfp217 KO mice. (B) PCR-based genotyping of Zfp217 KO and WT alleles. (C) Quantitative real-time PCR analysis of Zfp217 mRNA expression in inguinal white adipose tissue (iWAT), epididymal white adipose tissue (eWAT), brown adipose tissue (BAT), and liver of $\mathrm{Zfp} 217^{+/+}$and $\mathrm{Zfp} 217^{+/-}$mice ( $n=8$ per group). For all statistical plots, data are presented as the mean \pm SEM. ${ }^{* *} p<0.01$.

\subsection{Zfp $217^{+/-}$Mice Exhibit a Similar Phenotype to Zfp $217^{+/+}$Mice under a Normal Chow Diet (NC)}

When maintained under a normal chow diet (NC) ad libitum, the Zfp217 ${ }^{+/-}$mice had similar body weight and food intake to $\mathrm{Zfp} 217^{+/+}$mice (Figure 2A; Supplemental Figure

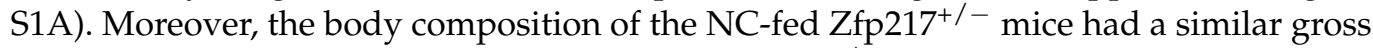
appearance and percentage total body fat as $\mathrm{Zfp} 217^{+/+}$mice (Figure 2B; Supplemental Figure S1B). iWAT, eWAT, and BAT pads were not significant between the Zfp217 $7^{+/+}$ mice and Zfp217 ${ }^{+/-}$mice (Supplemental Figure S1C,D). Histological observations also confirmed no obvious differences in sections of various adipose tissues (Supplemental

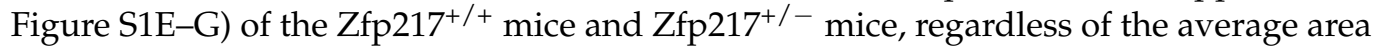
of adipocytes or the distribution of adipocyte diameters.

Furthermore, glucose homeostasis in the mice was assessed by glucose and insulin tolerance tests. The GTTs and ITTs revealed no differences between the $\mathrm{Zfp} 217^{+/+}$mice and $\mathrm{Zfp} 217^{+/-}$mice (Supplemental Figure S2A-D). In addition, we also measured the oxygen consumption (VO2) and $\mathrm{CO} 2$ production (VCO2) rates of both genotypes by indirect calorimetry to determine energy expenditure. The physical activity and respiratory exchange ratio were comparable between genotypes (Supplemental Figure S3A,B). Consistent with the physical activity, Zfp217 ${ }^{+/-}$mice showed similar VO2 and VCO2 as well as energy expenditure in light phases when compared with Zfp217 ${ }^{+/+}$mice (Supplemental Figure S3C,D), but Zfp217 $7^{+-}$mice showed increased VO2 as well as increased energy expenditure in dark phases when compared with $\mathrm{Zfp} 217^{+/+}$mice (Supplemental Figure S3C-E). Collectively, these data provide evidence that Zfp217 $7^{+/-}$mice had no defective adipocyte differentiation ability and normal adipose tissues under NC. Possibly because we used a constitutive whole-body heterozygous knockout mice model, the possibility that compensatory responses mask the requirement for Zfp217 in metabolic homeostasis in the basal state cannot be excluded. Future studies employing conditional $\mathrm{KO}$ of Zfp217 in adult mice will help address this issue. 
A $\because \mathrm{Zfp} 217^{+/+}-\mathrm{NC} \rightarrow \mathrm{Zfp} 217^{+/+}-\mathrm{HFD}$

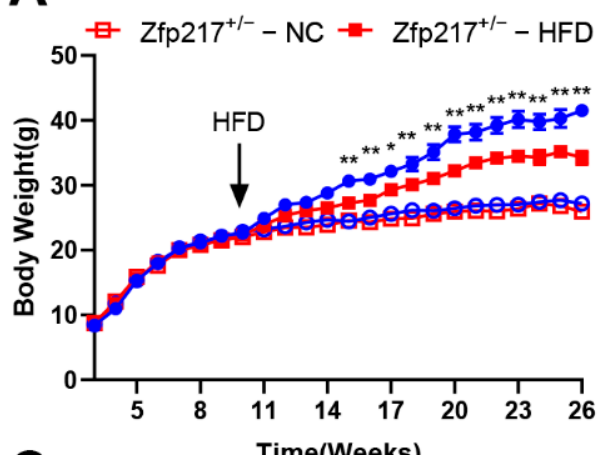

C
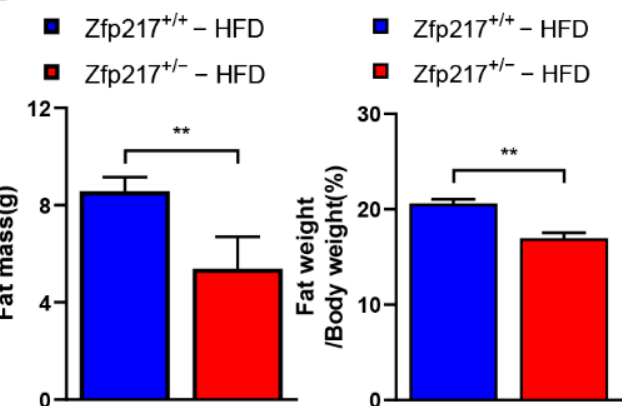

E. Zfp $217^{+/+}-\mathrm{HFD}$

- $\mathrm{Zfp} 217^{+/-}-$HFD

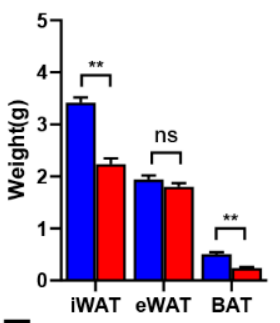

$\mathbf{F}$

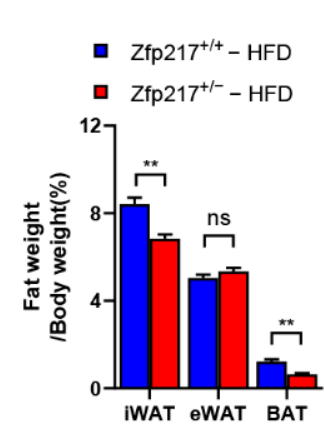

EWAT

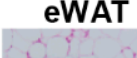

iWAT

Zfp217+/+ - HFD
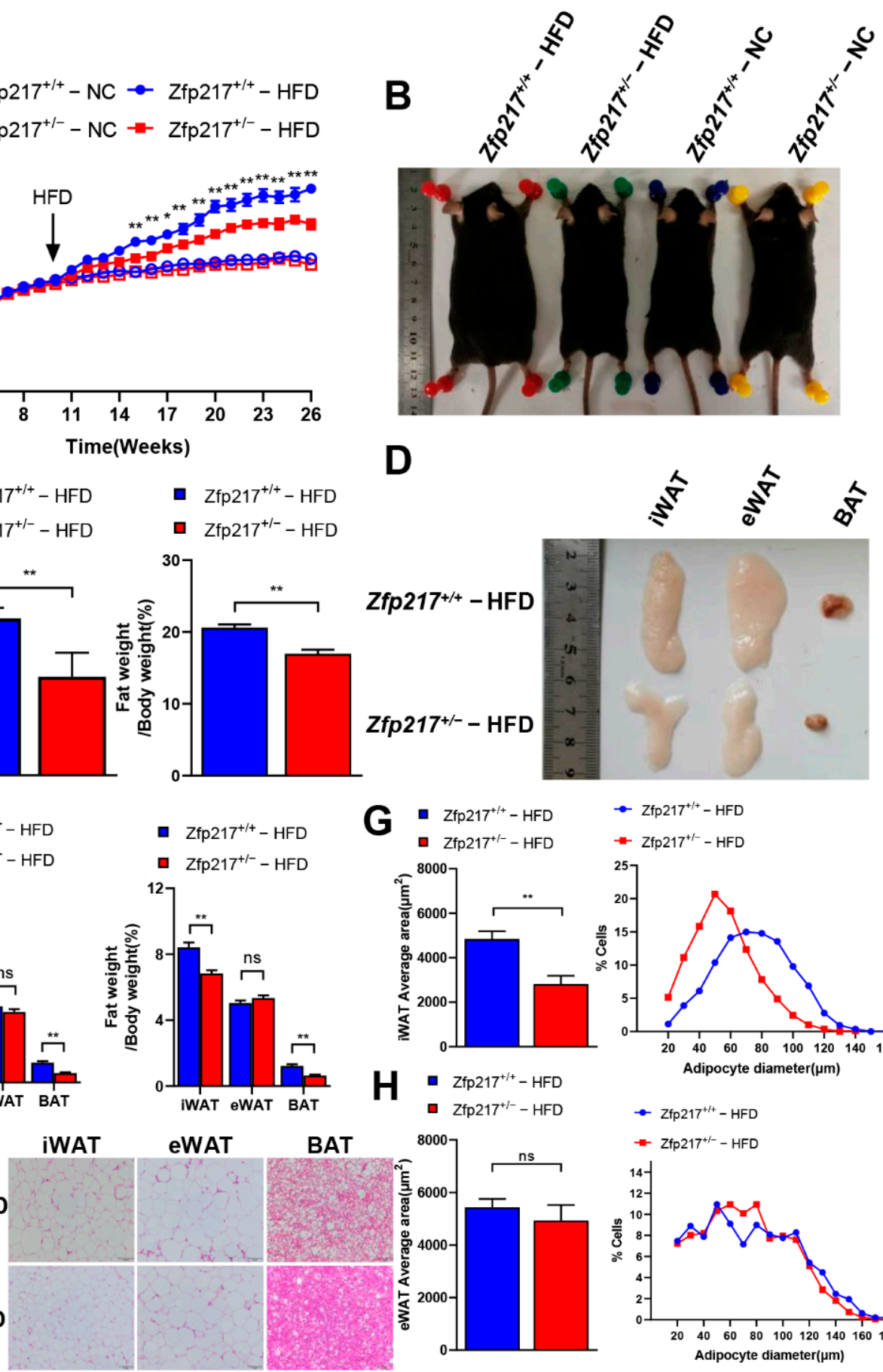

G $2 \mathrm{fp} 217^{+/+}-\mathrm{HFD}$

- Zffp217 $7^{+/+}-\mathrm{HFD}$

- Zfp217 $17^{+1-}-\mathrm{HFD}$

- Zfp $217^{+1-}-$ HFD
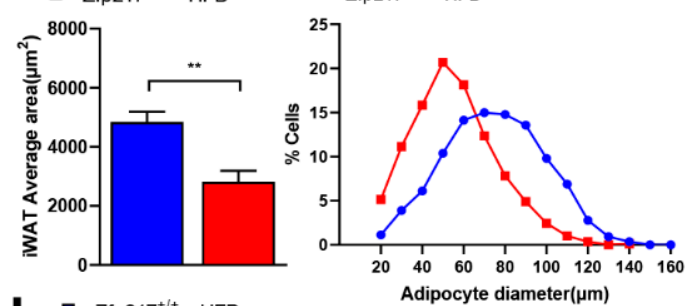

H. $\begin{aligned} & \mathrm{Zfp} 217^{+/+}-\mathrm{HFD} \\ & \text { a } \mathrm{Zfp} 217^{+/-}-\mathrm{HFD}\end{aligned}$

$\rightarrow Z \mathrm{fp} 217^{+/+}-$HFD
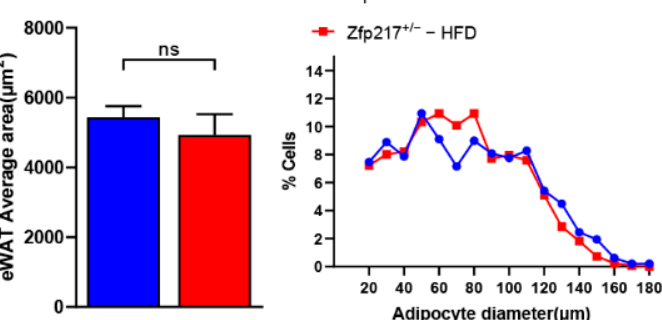

Adipocyte diameter $(\mu \mathrm{m})$

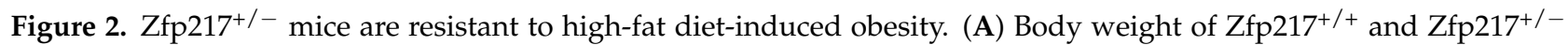
mice fed a normal chow diet (NC) for 10 weeks and then switched to a high-fat diet (HFD) for 16 weeks ( $n=8$ per group).

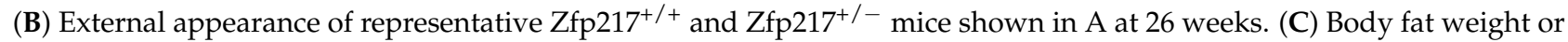
percentage of $\mathrm{Zfp} 217^{+/+}$and $\mathrm{Zfp} 217^{+/-}$mice ( $n=8$ per group). (D) Gross appearance of adipose tissues from representative

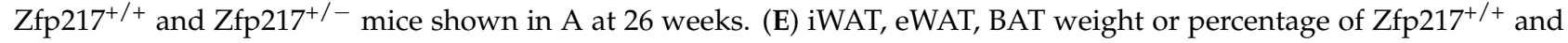
Zfp217 ${ }^{+/-}$mice ( $n=8$ per group). (F) H\&E staining of adipose tissue from Zfp217+/+ and Zfp217 ${ }^{+/-}$mice (Scale bar: $100 \mu \mathrm{m})(n=6$ per group). (G,H) Average cell area (left) and adipocyte size distribution (right) in iWAT (G) and eWAT

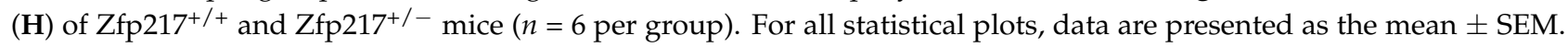
${ }^{*} p<0.05 ;{ }^{* *} p<0.01 ;$ ns indicates no significance between the two indicated groups. 


\subsection{Zfp217 Knockout Mice Are Resistant to Diet-Induced Obesity}

To investigate the effects of high-fat diet (HFD) treatment, a cohort of 10-week-old Zfp $217^{+/+}$and Zfp217 $7^{+/-}$male mice were fed ad libitum a diet containing $60 \%$ fat for

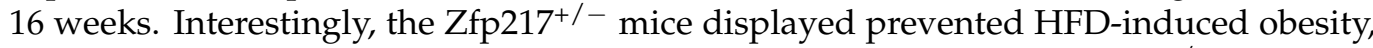
and their body-weight gain was significantly slower than that of the $\mathrm{Zfp} 217^{+/+}$mice after 16 weeks of HFD feeding (Figure 2A). However, there was no difference in food intake between $\mathrm{Zfp} 217^{+/+}$mice and Zfp217 $7^{+/}$mice (Supplemental Figure S1A). We found that

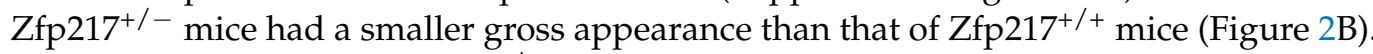
We found that HFD-fed Zfp217 $7^{+-}$mice had an extremely significantly lower fat weight and percentage total body fat than those of $\mathrm{Zfp} 217^{+/+}$mice (Figure 2C). Further analysis revealed that iWAT and BAT pads were smaller in $\mathrm{Zfp} 217^{+/-}$mice than in $\mathrm{Zfp} 217^{+/+}$ mice, but eWAT pads showed no difference between $\mathrm{Zfp} 217^{+/+}$mice and Zfp217 ${ }^{+/-}$mice (Figure 2E). Subsequently, sections of iWAT and BAT of Zfp217 ${ }^{+/+}$mice and $\mathrm{Zfp} 217^{+/-}$ mice showed obvious differences by histological observation, but not eWAT (Figure 2F). To determine whether the reduction in the size of the fat pad was because of fewer cell numbers or smaller adipocytes, we examined the inguinal fat tissue sections and found that the average area and the size distribution of adipocyte were smaller in the $\mathrm{Zfp} 217^{+/-}$ mice adipose tissues than those of the $\mathrm{Zfp}_{21} 7^{+/+}$mice (Figure $2 \mathrm{G}$ ). However, we found that the average area of adipocytes and the distribution of adipocyte diameters did not differ in the eWAT of $\mathrm{Zfp} 217^{+/+}$mice and Zfp217 $7^{+/-}$mice (Figure $2 \mathrm{H}$ ). A comparison between the average area of inguinal adipocytes (Figure $2 \mathrm{H}$ ) and the average inguinal fat pad weight (Figure 2E) suggested that the reduced total fat accumulation in Zfp217 $7^{+/-}$ mice was primarily because of the reduced size of the inguinal adipocytes.

A high-fat diet causes disturbances in glucose metabolism in mice [30]. The GTT and ITT reflect the body's ability to regulate glucose and the peripheral tissue's sensitivities response to insulin, respectively $[31,32]$. The GTT results showed that the $\mathrm{Zfp}_{217^{+/-}}$ mice exhibited improved glucose clearance compared with $\mathrm{Zfp} 217^{+/+}$mice (Figure 3A,B). Correspondingly, Zfp217 $7^{+/-}$mice were also more sensitive to insulin than $\mathrm{Zfp} 217^{+/+}$ mice, as determined by ITT (Figure 3C,D). Together, these data suggest that loss of Zfp217 expression ameliorates HFD-induced obesity-related metabolic syndrome including insulin resistance and glucose intolerance.

\subsection{Zfp217 Knockout Mice Demonstrate Increased Energy Expenditure}

To investigate whether Zfp217 deficiency might cause alterations in energy metabolism, we next measured the mice for several metabolic parameters. Surprisingly, indirect calorimetry analysis revealed that the total volume of carbon dioxide production $\left(\mathrm{VCO}_{2}\right)$ and oxygen consumption $\left(\mathrm{VO}_{2}\right)$ were significantly higher in HFD-fed Zfp217 $7^{+/-}$mice than in Zfp217 $7^{+/+}$mice during both light and dark phases (Figure 4C,D). Correspondingly, energy expenditure rate (EE) was significantly increased in Zfp217 $7^{+/-}$mice during both light and dark compared to Zfp217 ${ }^{+/+}$mice (Figure 4E). Since no differences were observed in physical activity or the respiratory exchange ratio (Figure 4A,B), we therefore concluded that higher energy expenditure in HFD-fed $\mathrm{Zfp} 217^{+/-}$mice is the primary mechanism facilitating their resistance to adiposity and body-weight gain. 

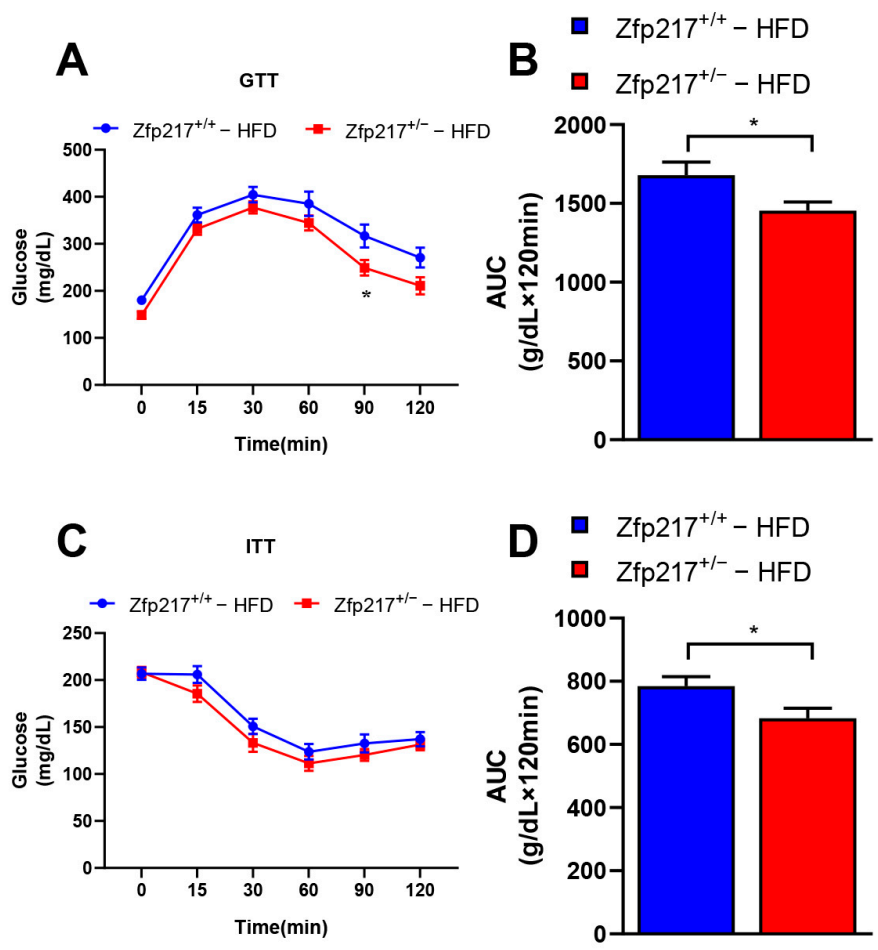

Figure 3. Zfp217 deficiency improves glucose tolerance and insulin sensitivity under HFD. (A,B) IP

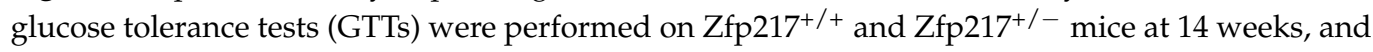
the corresponding areas under the curves were calculated ( $n=8$ per group). Comparison at each time point was made against $\mathrm{Zfp} 217^{+/+}$control mice by two-way ANOVA. (C,D) IP insulin tolerance test (ITT) was performed on $\mathrm{Zfp} 217^{+/+}$and $\mathrm{Zfp} 217^{+/-}$mice at 15 weeks, and the corresponding areas under the curves were calculated ( $n=8$ per group). Comparison at each time point was made against Zfp $217^{+/+}$control mice by two-way ANOVA. For all statistical plots, data are presented as the mean \pm SEM. ${ }^{*} p<0.05$.

\subsection{Impact of Zfp217 Deletion on Gene Expression in Inguinal Adipose Tissue}

Our previous study showed that Zfp217 is positively correlated with triglyceride accumulation and can promote fat accumulation through post-transcriptional modification of m6A [25,27]. Similarly, we found that Zfp217 deletion causes resistance to HFD-induced obesity in in vivo experiments, possibly due to reduced adipogenesis or increased metabolic thermogenesis. To test the possibility, we selected the most important genes related to adipogenesis and lipid metabolism. Subsequently, we examined their expression in the inguinal fat tissue of Zfp217 $7^{+/+}$and Zfp217 $7^{+-}$mice fed an HFD for 16 weeks. We found that the mRNA expression levels of adipogenesis-related genes (PPAR $\gamma, \mathrm{CEBP} \alpha, \mathrm{AP} 2$, adiponectin, and FAS) in the inguinal adipose tissue of high-fat-fed Zfp217 $7^{/-}$mice were significantly lower than those of $\mathrm{Zfp} 217^{+/+}$mice, whereas the mRNA expression levels of lipid metabolism-related genes (PGC-1 $\alpha$ ) were extremely significantly higher than those of Zfp217 ${ }^{+/+}$mice (Figure 5A). At the same time, we also found that the protein expression of adipogenesis-related genes (PPAR $\gamma, \mathrm{AP} 2$, and FAS) and lipid metabolism-related genes (PGC-1 $\alpha$ ) showed the same trend (Figure 5B). The data suggest that the reduction of Zfp217 activity can alter the expression of genes and inhibit impairment of adipose tissue lipid storage. The differential expression of genes may be the molecular cause of resistance to high-fat diet-induced obesity. 


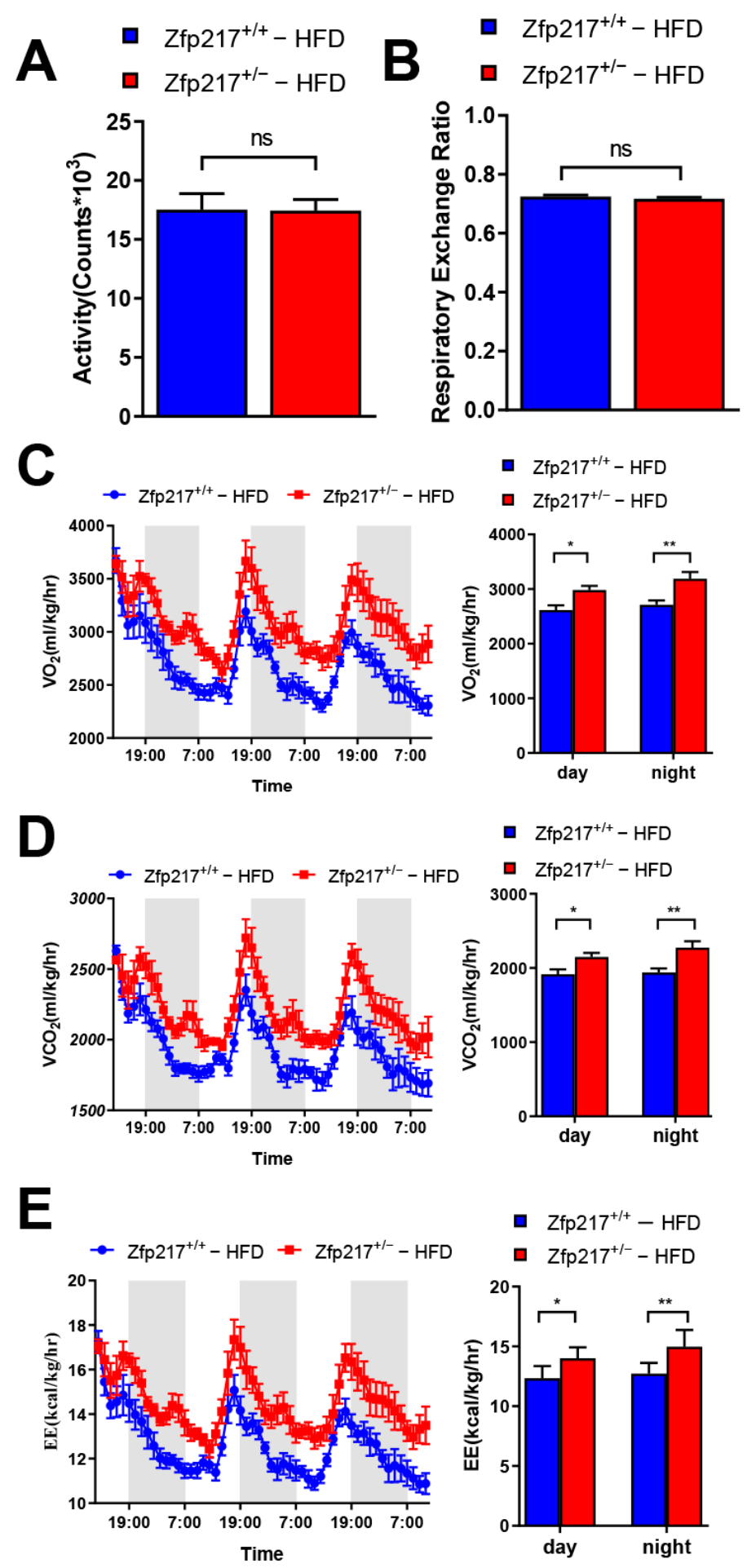

Figure 4. Zfp217 deficiency increases energy expenditure under HFD. (A) Physical activity, (B) Respiratory exchange ratio (C) Oxygen consumption $\left(\mathrm{VO}_{2}\right)$, (D) Carbon dioxide generation $\left(\mathrm{VCO}_{2}\right)$, and (E) Energy consumption analyzed by indirect calorimetry in $\mathrm{Zfp} 217^{+/+}$and $\mathrm{Zfp}^{217^{+/-}}$ mice after HFD feeding at 25 weeks ( $n=6$ per group). For all statistical plots, data are presented as the mean \pm SEM. ${ }^{*} p<0.05 ;{ }^{* *} p<0.01$; ns indicates no significance between the two indicated groups. 
A IWAT Adipogenesis

\section{Lipid metabolism}

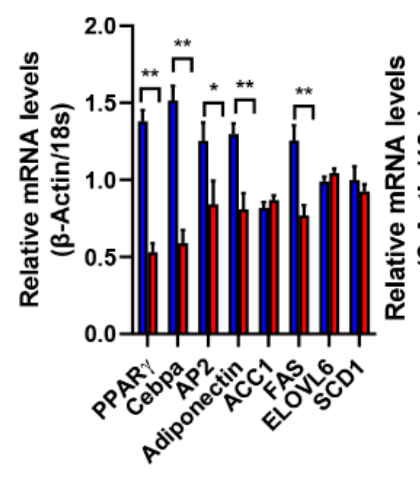

B
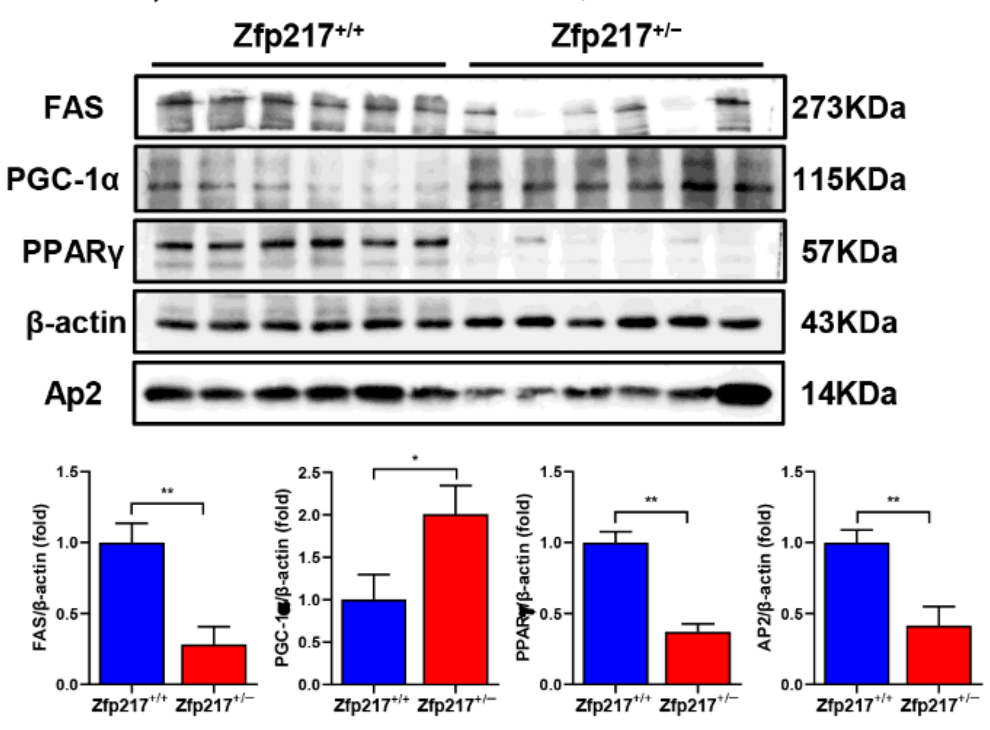

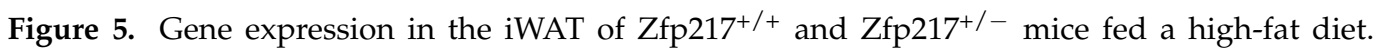
(A) Quantitative real-time PCR analysis of genes involved in adipogenesis and lipid metabolism

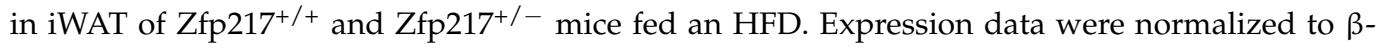
actin and the $18 \mathrm{~S}$ geometric mean in each sample ( $n=6$ per group). (B) Western blotting analysis of genes involved in adipogenesis and lipid metabolism in iWAT of Zfp217 ${ }^{+/+}$and $\mathrm{Zfp}^{217^{+/-}}$ mice fed an HFD. Expression data were normalized to the $\beta$-actin geometric mean in each sample ( $n=6$ per group). For all statistical plots, data are presented as the mean \pm SEM. ${ }^{*} p<0.05 ;{ }^{* *} p<0.01$.

\subsection{Zfp217 Knockout Mice Exhibit Reduced Adipogenesis}

To determine the role of Zfp217 in adipogenesis in Zfp217 knockout mice, we examined adipogenic differentiation potential in vitro. MEF cells were isolated from an E14.5 d embryo and induced in an adipogenic culture medium as described in Materials and Methods. The differentiation was assessed by examining lipid accumulation and determining gene expression. Compared to Zfp217 $7^{+/+}$cells, Oil Red O staining demonstrated that Zfp217 ${ }^{+/-}$MEF had fewer lipid droplets (Figure 6A). This result was similar to that of the triglyceride content measurement. The triglyceride content in differentiated adipocytes

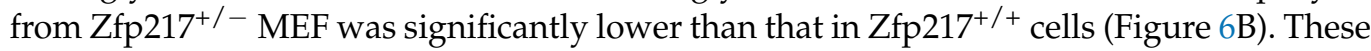
results suggest a decreased adipogenic potential in Zfp217-deficient cells. We examined the expression of transcription factors (PPAR $\gamma$ and $\mathrm{C} / \mathrm{EBP} \alpha$ ) that are required for adipocyte differentiation. After differentiation, $\mathrm{Zfp} 217^{+/-}$cells had an extremely significant reduction in mRNA and protein for PPAR $\gamma$ and AP2 (Figure $6 \mathrm{C}, \mathrm{D}$ ). There were also extremely significant changes in mRNA for $\mathrm{C} / \mathrm{EBP} \alpha$ and adiponectin (Figure $6 \mathrm{C}$ ). The results imply that Zfp217 deletion inhibits adipogenesis of MEFs cells, which is consistent with the in vivo level data. 

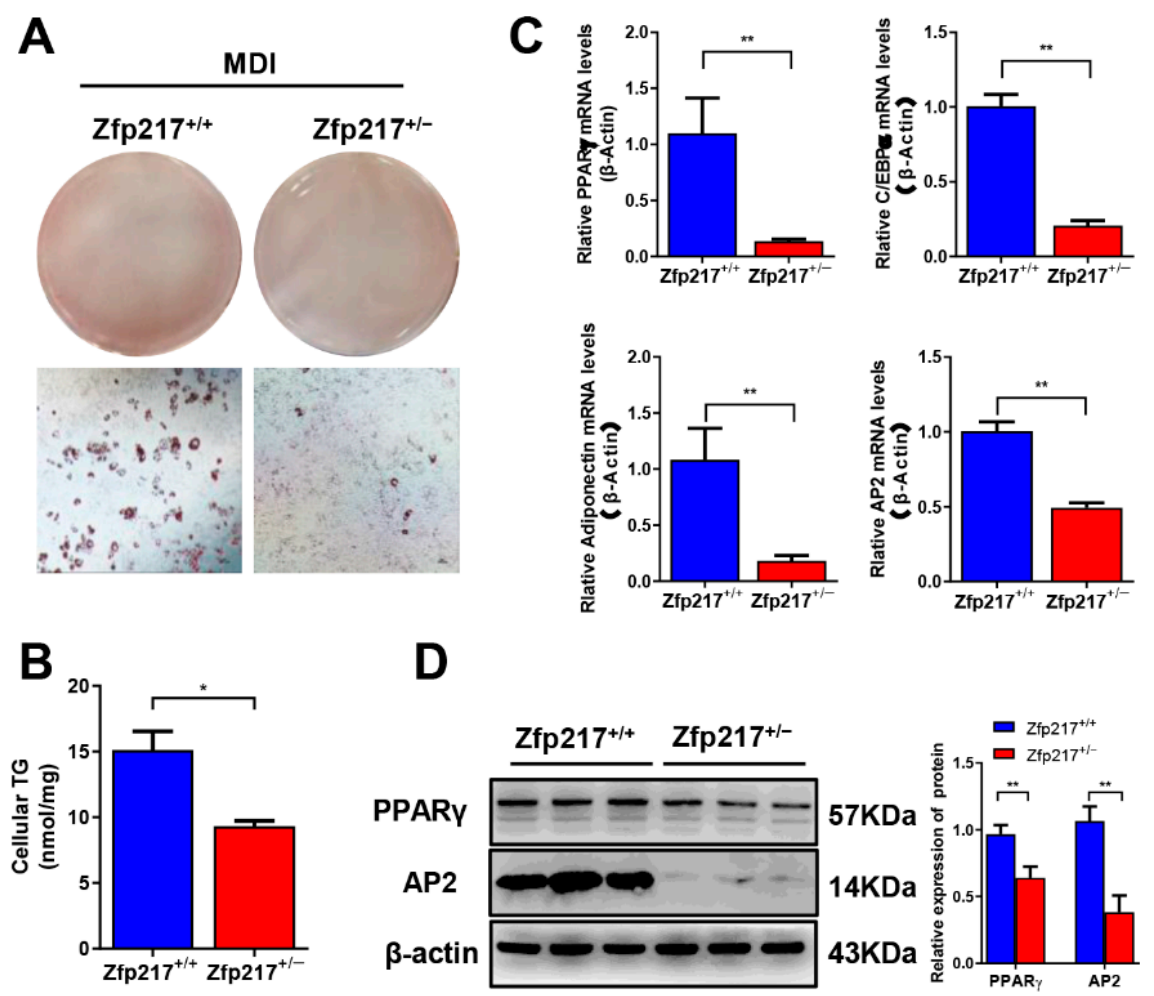

Figure 6. Zfp217 deficiency impaired adipogenesis in vitro. (A) Oil red-O staining of lipids in differentiated cells (Scale bar: $100 \mu \mathrm{m}$ ) ( $n=3$ per group). (B) A triglyceride assay kit was used for analysis of the content of triglycerides ( $n=3$ per group). (C) mRNA expression levels of PPAR $\gamma$, $\mathrm{C} / \mathrm{EBP} \alpha$, adiponectin, and AP2 in differentiated cells were measured by quantitative real-time PCR analysis ( $n=3$ per group). (D) Protein expression of Zfp217, PPAR $\gamma$, and AP2 in differentiated cells were measured by Western blotting ( $n=3$ per group). For all statistical plots, data are presented as the mean \pm SEM. ${ }^{*} p<0.05 ;{ }^{* *} p<0.01$.

\section{Discussion}

A series of factors have been reported to be involved in the process of adipocyte differentiation, and the molecular regulatory mechanisms of adipogenesis have been systematically summarized $[14,33]$. PPAR $\gamma$ and C/EBP $\alpha$ have emerged as master regulators of adipogenesis, which oversee the entire terminal differentiation process $[34,35]$. Understanding the transcriptional cascade regulatory network of these factors and the mechanisms regulating adipogenesis is of great significance for the treatment of obesity.

It is well known that ZFP217, which a member of the histone complex repressors, is involved in many biological processes, including tumorigenesis and embryonic development $[28,36,37]$. Recently, it has been reported that Zfp217 levels are positively associated with triglycerides, and knockdown of Zfp217 hinders adipogenic differentiation by reducing the expression of key lipogenic genes $\operatorname{PPAR} \gamma, \mathrm{C} / \mathrm{EBP} \alpha, \mathrm{Ap} 2$, and adiponectin in 3T3-L1 cells, which means Zfp217 has a potential effect on obesity [25,26]. Based on these results, to better understand the impact of Zfp217 loss on obesity, we sought to address the effect of Zfp217 deficiency on metabolic homeostasis by establishing a novel mouse model heterozygous for the Zfp217 gene using the CRISPR/Cas9 system. In our study, we found that the detection of adipogenesis-related genes $\operatorname{PPAR} \gamma, \mathrm{C} / \mathrm{EBP} \alpha, \operatorname{Ap} 2$, and adiponectin in iWAT and MEFs showed a significant decrease after Zfp217 deletion (Figures 5A and 6C,D). This is consistent with previous research. These data imply that the expression of Zfp217 is significantly positively correlated with the expression of adipogenic genes such as PPAR $\gamma, \mathrm{C} / \mathrm{EBP} \alpha$, and Ap2. In vitro studies and mice models with high fat diets showed that Zfp217 plays a key role in adipogenesis. 
Consistent excessive caloric intake usually leads to increased fat deposition, mainly in the subcutaneous fat cells [38]. In addition, there are also reports in the literature that white adipose tissue can be divided into subcutaneous adipose depots (e.g., inguinal adipose tissue) and visceral adipose tissue (e.g., epididymal adipose tissue) according to anatomical location [39]. In obesity, visceral fat can expand by increasing the size of adipocytes, while subcutaneous fat enlarges mainly by increasing the size or number of adipocytes to adapt and expand to excess energy [40,41]. Simultaneously, our study further confirms that Zfp $217^{+/-}$mice can resist obesity because they have smaller and fewer adipocytes in inguinal adipose tissue in vivo (Figure 2A,D-G). Our results are in agreement with those reported earlier. Once adiposity accumulates, adipose tissue dysfunction leads to the production of a series of metabolic syndromes, including insulin resistance as the dominant feature $[42,43]$. In this study, we found that obese Zfp $217^{+/+}$mice had significantly poorer glucose tolerance and insulin sensitivity than $\mathrm{Zfp}_{217^{+/}}$mice (Figure 3). Our data further indicate that Zfp217 knockout mice had reduced body fat, which protected against high-fat diet-induced insulin resistance.

In general, changes in body weight are closely related to physical activity and energyproducing metabolism besides the body's feeding activity and material metabolism [30]. In the present study, we found that obesity in $\mathrm{Zfp}^{2} 17^{+/+}$mice was not because of their excessive energy intake or less physical activity than that of $\mathrm{Zfp}_{217^{+/-}}$mice (Figure 4A and Figure S1A). It has been reported that total oxygen consumption is reduced and mitochondrial activity is decreased under obese condition [44]. As observed in this experiment, Zfp217 $7^{+/+}$mice fed high-fat diets showed a significant decrease in oxygen consumption, but Zfp217 $7^{+/-}$mice could recover this phenotype (Figure 4C). Surprisingly, we newly found that Zfp217 can affect the expression of PGC-1 $\alpha$, which resists obesity by increasing the thermogenic capacity of the body. (Figure 5A,B), in addition to participating in the adipogenic process. It is now well established that PGC- $1 \alpha$ acts as a transcriptional cofactor involved in a variety of biological processes including adaptive thermogenesis, mitochondrial formation, glucose and fatty acid metabolism and is closely associated with diseases such as obesity and type 2 diabetes [45-47]. Previously reported functions of Zfp217 were mainly related to lipogenic differentiation, and this provides new ideas and insights into our understanding of Zfp217 regulation of obesity.

\section{Conclusions}

In conclusion, we describe the effects of Zfp217 deficiency on whole-body glucose and insulin levels and thermogenesis in a basal state and in diet-induced obesity. We found that $\mathrm{Zfp} 217^{+/-}$mice were comparable to $\mathrm{Zfp} 217^{+/+}$mice on a normal chow diet, but $\mathrm{Zfp} 217^{+/-}$mice were resistant to high-fat diet-induced obesity and were insulin resistant with improved glucose hemostasis. The present study showed that Zfp217 could function by regulating related genes acting on both adipogenesis and lipid metabolism pathways, but the specific molecular mechanisms still need to be investigated in depth. Therefore, our results highlight that Zfp217 may be a novel target to reduce obesity and its related complications in patients.

\section{Materials and Methods}

\subsection{Generation of Genetically Modified Mice}

Whole-body Zfp217-knockout C57BL/6J mice were constructed via CRISPR/Cas9 technology. sgRNAs targeting the mouse Zfp217 were designed using the CRISPR online design tool (http:/ / crispr.mit.edu/, accessed on 22 April 2021). sgRNAs sequences were as follows: sgRNA1: TGCTGTGCCCATAAAAGGGC, sgRNA2: CATAAGGACTCCTTCACGTA. Off-target analysis for sgRNA2 and amplifications for each primer pair (Table S2) were carried out separately. The PCR products were incubated at $37^{\circ} \mathrm{C}$ for 15 min with T7E1 enzyme and were examined by $1.5 \%$ agarose gel. The sgRNAs and Cas 9 nuclease were injected into fertilized oocytes. In this study, we generated 12 heterozygous knockout mice by CRISPR/Cas9 technology. Six of these mice (\#1, \#4, \#6, \#7, \#12, and \#14) 
had deletions of $>300 \mathrm{bp}$ fragment, while the remaining six mice $(\# 2, \# 8, \# 9, \# 10$, \#11, and $\# 13$ ) only had $<50 \mathrm{bp}$ fragment deletions. For easy genotype identification and maximum speed of breeding, we selected male mice with $>300 \mathrm{bp}$ deletion (\#12) as the F0 generation germline mice. The heterozygous $\mathrm{KO}\left(\mathrm{Zfp} 217^{+/-}\right)$and wild-type (Zfp217 $\left.{ }^{+/+}\right)$littermates were used in the study. These mice were maintained at $23 \pm 1{ }^{\circ} \mathrm{C}$ with a $12 \mathrm{~h}$ light/dark cycle and were housed in plastic boxes with free access to water and diet. All procedures were performed in accordance with the institutional animal care and use committees at Huazhong Agricultural University.

\subsection{Diets}

An obesity murine model was established by feeding a normal chow diet (NC; $10 \%$ fat, 70\% carbohydrates, and 20\% protein; D12450B) for 10 weeks and then switched to a high-fat diet (HFD; 20\% protein, 60\% fat, and 20\% carbohydrates; D12492) for 16 weeks. Mice that were fed an NC post weaning until 26 weeks of age served as controls. The feed intake and body weight were recorded weekly.

\subsection{Genotype Identification}

Mice were weaned at three weeks of age. DNA was prepared from tail samples using the Mini BEST Universal Genomic DNA Extraction Kit Ver 5.0 according to the manufacturer's instructions (Japan, TAKARA, \#9765). PCR analysis was used for genotyping and was performed with a Bio-Rad machine. Zfp217-KO and wild-type alleles were detected by PCR assays in which primer F1 (5'-TCGTGCTGACGCACATCTGACTC-3') and primer R1 (5'-GGGTTCCTCTCGGTGGTCATCAG-3') amplified a 1008-bp fragment (WT) and a 650-bp fragment (Zfp217-KO).

\subsection{Tissue Isolation}

At 26 weeks of age, the mice were fasted for $12 \mathrm{~h}$ and sacrificed under anesthesia. Samples included inguinal fat, epididymal fat, brown fat, and liver. Samples were fixed in $4 \%$ paraformaldehyde at room temperature and processed for histology. The frozen samples for protein and mRNA analysis were kept at $-80{ }^{\circ} \mathrm{C}$.

\subsection{Glucose and Insulin Tolerance Test}

Intraperitoneal glucose tolerance test (IP-GTT) and intraperitoneal insulin tolerance test (IP-ITT) were performed as previously described [48]. The process as follows: IP-GTT and IP-ITT were performed after 14 and 15 weeks of NCD or HFD feeding, respectively. The fasting blood glucose levels $(t=0)$ were measured using a glucometer (Roche, ACCU-Chek active) after either $16 \mathrm{~h}$ for IP-GTT or $6 \mathrm{~h}$ for IP-ITT. Then, glucose $(2 \mathrm{~g} / \mathrm{kg})$ was injected to the mice intraperitoneally, and blood was collected from tail veins to measure glucose level at 15, 30, 60, 90, and $120 \mathrm{~min}$. For IP-ITT, mice were administered intraperitoneal injections at a dosage of $1 \mathrm{U} / \mathrm{kg}$. All other procedures were identical to those presented above. The trapezoidal method was used to calculate the area under the curve (AUC).

\subsection{Indirect Calorimetry}

Indirect calorimetry was performed using the Panlab Oxylet Pro System (Spain, Panlab LE 405). Animals were individually placed in metabolic cages, and respiratory measurements were recorded for three consecutive days at 20-min intervals following an adaptation period of $9 \mathrm{~h}$. Then, the oxygen consumption rate $(\mathrm{VO} 2 ; \mathrm{mL} / \mathrm{kg} / \mathrm{h})$, carbon dioxide production rate $(\mathrm{VCO} 2 ; \mathrm{mL} / \mathrm{kg} / \mathrm{h})$, energy expenditure rate $(\mathrm{EE} ; \mathrm{kcal} / \mathrm{kg} / \mathrm{h})$, respiratory exchange ratio (RER; VCO2/VO2), and activity were measured for $3 \mathrm{~d}$. The energy expenditure rate was calculated using the following equation: Energy expenditure rate $=3.815 \times \mathrm{VO} 2+$ $1.232 \times$ VCO2. The metabolic data were normalized regarding body weight. 


\subsection{Hematoxylin and Eosin (HEE) Staining}

Freshly harvested adipose tissues were fixed in $4 \%$ paraformaldehyde, and an $8 \mu \mathrm{m}$ cross-section of adipose tissue was processed with a standard procedure.

\subsection{Quantitative Image Analysis}

Representative images were acquired using a light microscope (Japan, Tokyo, Olympus, Olympus BX53). The average cell area and size of adipocytes were analyzed by Image $\mathrm{J}$ pro plus. Five fields were randomly selected in each sample, and the area and diameter of adipocytes were measured at $200 \times$ magnification. Average diameter was calculated from the number of measured adipocytes.

\subsection{RNA Extraction, cDNA Synthesis, and Quantitative Real-Time PCR}

Total RNA was extracted from frozen adipose tissues or cells using Trizol (Japan, TAKARA, \#9109). cDNA was synthesized by reverse transcription of $1 \mu \mathrm{g}$ RNA using the Prime Script First-Strand cDNA Synthesis Kit (Japan, TAKARA, \#RR047A) according to the manufacturer's instructions. The cDNA was quantified by qRT-PCR using the SYBR Green PCR Kit (Germany, Qiagen, \#208054). The reaction was performed as follows: $95^{\circ} \mathrm{C}$ for $5 \mathrm{~min}$ and 40 cycles of $95^{\circ} \mathrm{C}$ for $30 \mathrm{~s}, 60^{\circ} \mathrm{C}$ for $30 \mathrm{~s}$, and $72{ }^{\circ} \mathrm{C}$ for $30 \mathrm{~s}$. The reactions were conducted using an ABI QuantStudio TM 6 flex (United States, Applied Biosystems). Primers used in the PCR are listed in Supplementary Materials, Table S1. The comparative $\mathrm{Ct}\left(2^{-\Delta \Delta \mathrm{Ct}}\right)$ method was used. The $\mathrm{Ct}$ values were normalized to the $\beta$-actin gene or $18 \mathrm{~s}$ in the same sample.

\subsection{Western Blotting}

Total protein was extracted from adipose tissues and MEFs cells using RIPA lysis buffer with protease inhibitors. All samples were centrifuged at 12,000 r/min for $10 \mathrm{~min}$ at $4{ }^{\circ} \mathrm{C}$, and the supernatants were collected. Protein concentrations were quantified by the Pierce ${ }^{\circledR}$ BCA Protein Assay Kit (United States, Thermo Fisher, \#23225). Proteins were separated with $10 \%$ SDS/PAGE gels and transferred to PVDF membranes. The membranes were probed with the following antibodies against PPAR $\gamma$ (China, ABclonal, \#A0270), aP2 (China, ABclonal, \#A0232), FAS (United States, CST, \#3180), PGC-1 $\alpha$ (China, ABclonal, \#A11971), and $\beta$-actin (China, ABclonal, \#AC004), then probed with HRP-conjugated secondary antibodies, and incubated with developing solution (United States, Bio-rad, $\# 170-5060)$. $\beta$-actin was used as the internal reference.

\subsection{Mouse Embryonic Fibroblasts (MEFs) and Adipogenesis}

MEFs were isolated from E14.5 d embryos and maintained as previously described [49]. MEFs were treated with differentiation medium (10\% fetal bovine serum (FBS) containing $0.5 \mu \mathrm{M}$ 3-isobutyl-1-methylxanthine, $1 \mu \mathrm{M}$ dexamethasone, $10 \mu \mathrm{g} / \mathrm{mL}$ of insulin, and $200 \mu \mathrm{M}$ indomethacin) for 4-6 d (medium was replaced every $2 \mathrm{~d}$ ), and then cultured in maintenance medium supplemented with $10 \% \mathrm{FBS}$ and $10 \mu \mathrm{g} / \mathrm{mL}$ insulin for $2 \mathrm{~d}$, followed by exchange with regular medium containing $10 \%$ FBS and incubated for four days (media were changed every $1 \mathrm{~d}$ ). The cells had an adipocyte phenotype, and lipid droplets were visible; only cells with $90 \%$ or higher differentiation after 14 days were used.

\subsection{Oil Red O Staining}

Oil Red staining was performed according to the protocol [50]. Briefly, the fully differentiated MEF cells were washed twice with PBS and then fixed with $4 \%$ paraformaldehyde for $0.5-1 \mathrm{~h}$. After removal of the paraformaldehyde, the cells were stained with oil red O dye ( $0.5 \mathrm{~g}$ of oil red $\mathrm{O}$ dry powder dissolved in $100 \mathrm{~mL}$ isopropanol then diluted with dd $\mathrm{H}_{2} \mathrm{O}$ in a 3:2 ratio) at $37^{\circ} \mathrm{C}$ for $1 \mathrm{~h}$. Followed by removal of the dye, washing was conducted twice in PBS. Finally, triglyceride accumulation was photographed with a Nikon microscope (Eclipse TS100; Nikon, Tokyo, Japan). 


\subsection{Statistical Analysis}

In this study, all data were graphed as the mean \pm SEM and were analyzed using GraphPad prism software. Student's t test (unpaired 2-tailed) was employed for comparison between two groups. Two-way ANOVA was used to examine interactions between multiple variables. $p<0.05$ is statistically significant and is denoted as ${ }^{*} p<0.05$ or ** $p<0.01$.

Supplementary Materials: The following are available online at https://www.mdpi.com/article/10 $.3390 /$ ijms22105390/s1. Figure S1. Zfp217//- mice exhibit no phenotypic alterations compared to

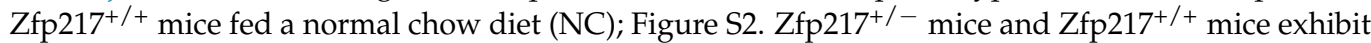
similar glucose tolerance and insulin sensitivity under NC; Figure S3. Zfp217 ${ }^{+/-}$mice exhibit no difference compared to the Zfp217 $7^{+/+}$mice in energy expenditure under NC; Figure S4. Detection of the five most likely off-target sites of sgRNA2' in the genome based on PCR and agarose gel electrophoresis; Table S1 Quantification real-time PCR primer sequence; Table S2 Primer design for off-target site.

Author Contributions: Conceived and designed the experiments: Q.Z. and S.J.; Performed the experiments and analyzed the data: Q.Z., N.W., Y.Z., Y.Y.; Drafted, wrote, and revised the manuscript: Q.Z., R.Z., J.C.; T.Q.; Generated figures: Q.Z., S.L. All authors discussed the results and commented on the manuscript. All authors have read and agreed to the published version of the manuscript.

Funding: This work was supported by the financial support of National Natural Science Foundation of China (31472075), The Fundamental Research Funds for the Central Universities (2662020DKPY012), and Key S \& T projects of Hubei Province (2020ABA016).

Institutional Review Board Statement: The study was conducted according to the guidelines of the Declaration of Helsinki, and approved by the Institutional Review Board (or Ethics Committee) of Huazhong Agricultural University (protocol code HZAUMO-2017-050).

Informed Consent Statement: Not applicable.

Data Availability Statement: No new data were created or analyzed in this study. Data sharing is not applicable to this article.

Conflicts of Interest: The authors declare no conflict of interest.

\section{References}

1. Van Kruijsdijk, R.C.M.; Van Der Wall, E.; Visseren, F.L.J. Obesity and Cancer: The Role of Dysfunctional Adipose Tissue. Cancer Epidemiol. Biomark. Prev. 2009, 18, 2569-2578. [CrossRef]

2. Flier, J.S. Obesity Wars: Molecular Progress Confronts an Expanding Epidemic. Cell 2004, 116, 337-350. [CrossRef]

3. Engin, A. The Definition and Prevalence of Obesity and Metabolic Syndrome. Adv. Exp. Med. Biol. 2017, 960, 1-17. [CrossRef] [PubMed]

4. Bagchi, D.P.; Li, Z.; Corsa, C.A.; Hardij, J.; Mori, H.; Learman, B.S.; Lewis, K.T.; Schill, R.L.; Romanelli, S.M.; MacDougald, O.A Wntless regulates lipogenic gene expression in adipocytes and protects against diet-induced metabolic dysfunction. Mol. Metab. 2020, 39, 100992. [CrossRef] [PubMed]

5. Després, J.-P.; Lemieux, I. Abdominal obesity and metabolic syndrome. Nat. Cell Biol. 2006, 444, 881-887. [CrossRef]

6. Trayhurn, P. Endocrine and signalling role of adipose tissue: New perspectives on fat. ACTA Physiol. Scand. 2005, 184, 285-293. [CrossRef] [PubMed]

7. Galic, S.; Oakhill, J.S.; Steinberg, G.R. Adipose tissue as an endocrine organ. Mol. Cell. Endocrinol. 2010, 316, 129-139. [CrossRef]

8. Kershaw, E.E.; Flier, J.S. Adipose Tissue as an Endocrine Organ. J. Clin. Endocrinol. Metab. 2004, 89, 2548-2556. [CrossRef] [PubMed]

9. Rosen, E.D.; Spiegelman, B.M. Adipocytes as regulators of energy balance and glucose homeostasis. Nat. Cell Biol. 2006, 444, 847-853. [CrossRef] [PubMed]

10. Tchkonia, T.; Thomou, T.; Zhu, Y.; Karagiannides, I.; Pothoulakis, C.; Jensen, M.D.; Kirkland, J.L. Mechanisms and Metabolic Implications of Regional Differences among Fat Depots. Cell Metab. 2013, 17, 644-656. [CrossRef]

11. Liu, Z.-J.; Zhuge, Y.; Velazquez, O.C. Trafficking and differentiation of mesenchymal stem cells. J. Cell. Biochem. 2009, 106, 984-991. [CrossRef] [PubMed]

12. Rosen, E.D. The transcriptional basis of adipocyte development. ProstaglandinsLeukot. Essent. Fat. Acids 2005, 73, 31-34. [CrossRef] [PubMed]

13. Tang, Q.Q.; Lane, M.D. Adipogenesis: From Stem Cell to Adipocyte. Annu. Rev. Biochem. 2012, 81, 715-736. [CrossRef] [PubMed]

14. Farmer, S.R. Transcriptional control of adipocyte formation. Cell Metab. 2006, 4, 263-273. [CrossRef] 
15. Rangwala, S.M.; Lazar, M.A. Transcriptional control of adipogenesis. Annu. Rev. Nutr. 2000, 20, 535-559. [CrossRef] [PubMed]

16. Sarjeant, K.; Stephens, J.M. Adipogenesis. CSH Perspect Biol. 2012, 4, a008417. [CrossRef]

17. Rosen, E.D.; Sarraf, P.; Troy, A.E.; Bradwin, G.; Moore, K.; Milstone, D.S.; Spiegelman, B.M.; Mortensen, R.M. PPAR gamma is required for the differentiation of adipose tissue in vivo and in vitro. Mol. Cell. 1999, 4, 611-617. [CrossRef]

18. Wu, Z.; Rosen, E.D.; Brun, R.; Hauser, S.; Adelmant, G.; Troy, A.E.; McKeon, C.; Darlington, G.J.; Spiegelman, B.M. Crossregulation of $\mathrm{C} / \mathrm{EBP}$ alpha and PPAR gamma controls the transcriptional pathway of adipogenesis and insulin sensitivity. Mol. Cell. 1999, 3, 151-158. [CrossRef]

19. Kintscher, U.; Law, R.E. PPAR $\gamma$-mediated insulin sensitization: The importance of fat versus muscle. Am. J. Physiol. Metab. 2005, 288, E287-E291. [CrossRef]

20. Wei, S.; Zhang, L.; Zhou, X.; Du, M.; Jiang, Z.; Hausman, G.J.; Bergen, W.G.; Zan, L.; Dodson, M.V. Emerging roles of zinc finger proteins in regulating adipogenesis. Cell. Mol. Life Sci. 2013, 70, 4569-4584. [CrossRef]

21. Oishi, Y.; Manabe, I.; Tobe, K.; Tsushima, K.; Shindo, T.; Fujiu, K.; Nishimura, G.; Maemura, K.; Yamauchi, T.; Kubota, N.; et al. Krüppel-like transcription factor KLF5 is a key regulator of adipocyte differentiation. Cell Metab. 2005, 1, 27-39. [CrossRef] [PubMed]

22. Gray, S.; Wang, B.; Orihuela, Y.; Hong, E.-G.; Fisch, S.; Haldar, S.; Cline, G.W.; Kim, J.K.; Peroni, O.D.; Kahn, B.B.; et al. Regulation of Gluconeogenesis by Krüppel-like Factor 15. Cell Metab. 2007, 5, 305-312. [CrossRef]

23. Buchner, D.A.; Charrier, A.; Srinivasan, E.; Wang, L.; Paulsen, M.T.; Ljungman, M.; Bridges, D.; Saltiel, A.R. Zinc Finger Protein 407 (ZFP407) Regulates Insulin-stimulated Glucose Uptake and Glucose Transporter 4 (Glut4) mRNA. J. Biol. Chem. 2015, 290, 6376-6386. [CrossRef] [PubMed]

24. Vandevenne, M.; Jacques, D.A.; Artuz, C.; Nguyen, C.D.; Kwan, A.H.; Segal, D.J.; Matthews, J.M.; Crossley, M.; Guss, J.; Mackay, J.P. New Insights into DNA Recognition by Zinc Fingers Revealed by Structural Analysis of the Oncoprotein ZNF217*. J. Biol. Chem. 2013, 288, 10616-10627. [CrossRef]

25. Xiang, H.; Zhong, Z.-X.; Peng, Y.-D.; Jiang, S.-W. The Emerging Role of Zfp217 in Adipogenesis. Int. J. Mol. Sci. 2017, 18, 1367. [CrossRef]

26. Liu, Q.; Zhao, Y.; Wu, R.; Jiang, Q.; Cai, M.; Bi, Z.; Liu, Y.; Yao, Y.; Feng, J.; Wang, Y.; et al. ZFP217 regulates adipogenesis by controlling mitotic clonal expansion in a METTL3-m6A dependent manner. RNA Biol. 2019, 16, 1785-1793. [CrossRef] [PubMed]

27. Song, T.; Yang, Y.; Wei, H.; Xie, X.; Lu, J.; Zeng, Q.; Peng, J.; Zhou, Y.; Jiang, S.; Peng, J. Zfp217 mediates m6A mRNA methylation to orchestrate transcriptional and post-transcriptional regulation to promote adipogenic differentiation. Nucleic Acids Res. 2019, 47, 6130-6144. [CrossRef] [PubMed]

28. Aguilo, F.; Zhang, F.; Sancho, A.; Fidalgo, M.; Di Cecilia, S.; Vashisht, A.; Lee, D.F.; Chen, C.H.; Rengasamy, M.; Andino, B.; et al. Coordination of m(6)A mRNA Methylation and Gene Transcription by ZFP217 Regulates Pluripotency and Repro-gramming. Cell Stem Cell. 2015, 17, 689-704. [CrossRef]

29. Kwak, S.; Kim, T.W.; Kang, B.-H.; Kim, J.-H.; Lee, J.-S.; Lee, H.-T.; Hwang, I.-Y.; Shin, J.; Lee, J.-H.; Cho, E.-J.; et al. Zinc finger proteins orchestrate active gene silencing during embryonic stem cell differentiation. Nucleic Acids Res. 2018, 46, 6592-6607. [CrossRef]

30. Winzell, M.S.; Ahren, B. The High-Fat Diet-Fed Mouse: A Model for Studying Mechanisms and Treatment of Impaired Glucose Tolerance and Type 2 Diabetes. Diabetes 2004, 53, S215-S219. [CrossRef]

31. Andrikopoulos, S.; Blair, A.R.; DeLuca, N.; Fam, B.C.; Proietto, J. Evaluating the glucose tolerance test in mice. Am. J. Physiol. Metab. 2008, 295, E1323-E1332. [CrossRef] [PubMed]

32. Andrikopoulos, S.; Massa, C.M.; Aston-Mourney, K.; Funkat, A.; Fam, B.C.; Hull, R.L.; Kahn, E.S.; Proietto, J. Differential effect of inbred mouse strain (C57BL/6, DBA/2, 129T2) on insulin secretory function in response to a high fat diet. J. Endocrinol. 2005, 187, 45-53. [CrossRef] [PubMed]

33. Rosen, E.D.; Spiegelman, B.M. Molecular Regulation of Adipogenesis. Annu. Rev. Cell Dev. Biol. 2000, 16, 145-171. [CrossRef]

34. Tontonoz, P.; Spiegelman, B.M. Fat and Beyond: The Diverse Biology of PPARgamma. Annu. Rev. Biochem. 2008, 77, 289-312. [CrossRef]

35. Rosen, E.D.; Hsu, C.H.; Wang, X.Z.; Sakai, S.C.; Freeman, M.W.; Gonzalez, F.J.; Spiegelman, B.M. C/EBPalpha induces adipogenesis through PPARgamma: A unified pathway. Genes Dev. 2002, 16, 22-26. [CrossRef]

36. Quinlan, K.G.; Verger, A.; Yaswen, P.; Crossley, M. Amplification of zinc finger gene 217 (ZNF217) and cancer: When good fingers go bad. Biochim. Biophys. ACTA Bioenerg. 2007, 1775, 333-340. [CrossRef]

37. Frietze, S.; O'Geen, H.; Littlepage, L.E.; Simion, C.; Sweeney, C.A.; JFarnham, P.; Krig, S.R. Global analysis of ZNF217 chromatin occupancy in the breast cancer cell genome reveals an association with ERalpha. BMC Genom. 2014, 15, 520. [CrossRef]

38. Patel, P.; Abate, N. Body Fat Distribution and Insulin Resistance. Nutrients 2013, 5, 2019-2027. [CrossRef] [PubMed]

39. Gesta, S.; Tseng, Y.-H.; Kahn, C.R. Developmental Origin of Fat: Tracking Obesity to Its Source. Cell 2007, 131, 242-256. [CrossRef]

40. Tchoukalova, Y.D.; Votruba, S.B.; Tchkonia, T.; Giorgadze, N.; Kirkland, J.L.; Jensen, M.D. Regional differences in cellular mechanisms of adipose tissue gain with overfeeding. Proc. Natl. Acad. Sci. USA 2010, 107, 18226-18231. [CrossRef] [PubMed]

41. Wang, A.Q.; Tao, C.; Gupta, R.K.; Scherer, P.E. Tracking adipogenesis during white adipose tissue development, expansion and regeneration. Nat. Med. 2013, 19, 1338-1344. [CrossRef]

42. Gustafson, B.; Hedjazifar, S.; Gogg, S.; Hammarstedt, A.; Smith, U. Insulin resistance and impaired adipogenesis. Trends Endocrinol. Metab. 2015, 26, 193-200. [CrossRef] 
43. Maffeis, C.; Morandi, A. Body composition and insulin resistance in children. Eur. J. Clin. Nutr. 2018, 72, 1239-1245. [CrossRef] [PubMed]

44. Yin, X.; Lanza, I.R.; Swain, J.M.; Sarr, M.G.; Nair, K.S.; Jensen, M.D. Adipocyte Mitochondrial Function Is Reduced in Human Obesity Independent of Fat Cell Size. J. Clin. Endocrinol. Metab. 2014, 99, E209-E216. [CrossRef] [PubMed]

45. Liang, H.; Ward, W.F. PGC-1 $\alpha$ : A key regulator of energy metabolism. Adv. Physiol. Educ. 2006, 30, 145-151. [CrossRef] [PubMed]

46. Finck, B.N.; Kelly, D.P. PGC-1 coactivators: Inducible regulators of energy metabolism in health and disease. J. Clin. Investig. 2006, 116, 615-622. [CrossRef] [PubMed]

47. Handschin, C.; Spiegelman, B.M. Peroxisome proliferator-activated receptor gamma coactivator 1 coactivators, energy homeostasis, and metabolism. Endocr. Rev. 2006, 27, 728-735. [CrossRef]

48. Wang, J.; Rajbhandari, P.; Damianov, A.; Han, A.; Sallam, T.; Waki, H.; Villanueva, C.J.; Lee, S.D.; Nielsen, R.; Mandrup, S.; et al. RNA-binding protein PSPC1 promotes the differentiation-dependent nuclear export of adipocyte RNAs. J. Clin. Investig. 2017, 127, 987-1004. [CrossRef]

49. Xu, F.; Gao, Z.; Zhang, J.; Rivera, C.A.; Yin, J.; Weng, J.; Ye, J. Lack of SIRT1 (Mammalian Sirtuin 1) activity leads to liver steatosis in the SIRT1+/- mice: A role of lipid mobilization and inflammation. Endocrinology 2010, 151, 2504-2514. [CrossRef] [PubMed]

50. Zhang, F.; Chen, K.; Tao, H.; Kang, T.; Xiong, Q.; Zeng, Q.; Liu, Y.; Jiang, S.; Chen, M. miR-25-3p, Positively Regulated by Transcription Factor AP-2 $\alpha$, Regulates the Metabolism of C2C12 Cells by Targeting Akt1. Int. J. Mol. Sci. 2018, 19, 773. [CrossRef] 